\title{
Appendix 1. PRISMA Checklist
}

\begin{tabular}{|c|c|c|c|}
\hline Section/topic & $\#$ & Checklist item & $\begin{array}{l}\text { Reported } \\
\text { on page } \\
\# \\
\end{array}$ \\
\hline \multicolumn{4}{|l|}{ TITLE } \\
\hline Title & 1 & Identify the report as a systematic review, meta-analysis, or both. & 1 \\
\hline \multicolumn{4}{|l|}{ ABSTRACT } \\
\hline Structured summary & 2 & $\begin{array}{l}\text { Provide a structured summary including, as applicable: background; objectives; data } \\
\text { sources; study eligibility criteria, participants, and interventions; study appraisal and } \\
\text { synthesis methods; results; limitations; conclusions and implications of key findings; } \\
\text { systematic review registration number. }\end{array}$ & $2-3$ \\
\hline \multicolumn{4}{|l|}{ INTRODUCTION } \\
\hline Rationale & 3 & Describe the rationale for the review in the context of what is already known. & 4-6 \\
\hline Objectives & 4 & $\begin{array}{l}\text { Provide an explicit statement of questions being addressed with reference to } \\
\text { participants, interventions, comparisons, outcomes, and study design (PICOS). }\end{array}$ & $5-6$ \\
\hline \multicolumn{4}{|l|}{ METHODS } \\
\hline Protocol and registration & 5 & $\begin{array}{l}\text { Indicate if a review protocol exists, if and where it can be accessed (e.g., Web address), } \\
\text { and, if available, provide registration information including registration number. }\end{array}$ & 6 \\
\hline Eligibility criteria & 6 & $\begin{array}{l}\text { Specify study characteristics (e.g., PICOS, length of follow-up) and report characteristics } \\
\text { (e.g., years considered, language, publication status) used as criteria for eligibility, giving } \\
\text { rationale. }\end{array}$ & $6-7$ \\
\hline Information sources & 7 & $\begin{array}{l}\text { Describe all information sources (e.g., databases with dates of coverage, contact with } \\
\text { study authors to identify additional studies) in the search and date last searched. }\end{array}$ & 7 \\
\hline Search & 8 & $\begin{array}{l}\text { Present full electronic search strategy for at least one database, including any limits } \\
\text { used, such that it could be repeated. }\end{array}$ & $\begin{array}{l}\text { 7, and } \\
\text { Appendix } \\
\text { S2 }\end{array}$ \\
\hline Study selection & 9 & $\begin{array}{l}\text { State the process for selecting studies (i.e., screening, eligibility, included in systematic } \\
\text { review, and, if applicable, included in the meta-analysis). }\end{array}$ & $7-8$ \\
\hline Data collection process & 10 & $\begin{array}{l}\text { Describe method of data extraction from reports (e.g., piloted forms, independently, in } \\
\text { duplicate) and any processes for obtaining and confirming data from investigators. }\end{array}$ & $8-9$ \\
\hline
\end{tabular}




\begin{tabular}{|l|r|l|c|}
\hline Data items & 11 & $\begin{array}{l}\text { List and define all variables for which data were sought (e.g., PICOS, funding sources) } \\
\text { and any assumptions and simplifications made. }\end{array}$ & $8-9$ \\
\hline $\begin{array}{l}\text { Risk of bias in individual } \\
\text { studies }\end{array}$ & 12 & $\begin{array}{l}\text { Describe methods used for assessing risk of bias of individual studies (including } \\
\text { specification of whether this was done at the study or outcome level), and how this } \\
\text { information is to be used in any data synthesis. }\end{array}$ & 9 \\
\hline Summary measures & 13 & State the principal summary measures (e.g., risk ratio, difference in means). & $8-9$ \\
\hline Synthesis of results & 14 & $\begin{array}{l}\text { Describe the methods of handling data and combining results of studies, if done, } \\
\text { including measures of consistency (e.g., } \text { I }^{2} \text { ) for each meta-analysis. }\end{array}$ & $8-9$ \\
\hline
\end{tabular}

\begin{tabular}{|c|c|c|c|}
\hline Section/topic & $\#$ & Checklist item & $\begin{array}{l}\text { Reported } \\
\text { on page \# }\end{array}$ \\
\hline $\begin{array}{l}\text { Risk of bias across } \\
\text { studies }\end{array}$ & 15 & $\begin{array}{l}\text { Specify any assessment of risk of bias that may affect the cumulative evidence (e.g., } \\
\text { publication bias, selective reporting within studies). }\end{array}$ & $\mathrm{n} / \mathrm{a}$ \\
\hline Additional analyses & 16 & $\begin{array}{l}\text { Describe methods of additional analyses (e.g., sensitivity or subgroup analyses, meta- } \\
\text { regression), if done, indicating which were pre-specified. }\end{array}$ & $\mathrm{n} / \mathrm{a}$ \\
\hline \multicolumn{4}{|l|}{ RESULTS } \\
\hline Study selection & 17 & $\begin{array}{l}\text { Give numbers of studies screened, assessed for eligibility, and included in the review, } \\
\text { with reasons for exclusions at each stage, ideally with a flow diagram. }\end{array}$ & $\begin{array}{l}9, \\
\text { Figure } 1\end{array}$ \\
\hline Study characteristics & 18 & $\begin{array}{l}\text { For each study, present characteristics for which data were extracted (e.g., study size, } \\
\text { PICOS, follow-up period) and provide the citations. }\end{array}$ & $10-11$ \\
\hline Risk of bias within studies & 19 & $\begin{array}{l}\text { Present data on risk of bias of each study and, if available, any outcome level } \\
\text { assessment (see item 12). }\end{array}$ & $\mathrm{n} / \mathrm{a}$ \\
\hline $\begin{array}{l}\text { Results of individual } \\
\text { studies }\end{array}$ & 20 & $\begin{array}{l}\text { For all outcomes considered (benefits or harms), present, for each study: (a) simple } \\
\text { summary data for each intervention group (b) effect estimates and confidence intervals, } \\
\text { ideally with a forest plot. }\end{array}$ & $\mathrm{n} / \mathrm{a}$ \\
\hline Synthesis of results & 21 & $\begin{array}{l}\text { Present results of each meta-analysis done, including confidence intervals and } \\
\text { measures of consistency. }\end{array}$ & $10-11$ \\
\hline $\begin{array}{l}\text { Risk of bias across } \\
\text { studies }\end{array}$ & 22 & Present results of any assessment of risk of bias across studies (see Item 15). & $\mathrm{n} / \mathrm{a}$ \\
\hline Additional analysis & 23 & $\begin{array}{l}\text { Give results of additional analyses, if done (e.g., sensitivity or subgroup analyses, } \\
\text { meta-regression [see Item 16]). }\end{array}$ & $\mathrm{n} / \mathrm{a}$ \\
\hline
\end{tabular}




\begin{tabular}{|l|c|l|c|}
\hline \hline DISCUSSION & 24 & $\begin{array}{l}\text { Summarize the main findings including the strength of evidence for each main outcome; } \\
\text { consider their relevance to key groups (e.g., healthcare providers, users, and policy } \\
\text { makers). }\end{array}$ & $11-14$ \\
\hline Summary of evidence & 25 & $\begin{array}{l}\text { Discuss limitations at study and outcome level (e.g., risk of bias), and at review-level } \\
\text { (e.g., incomplete retrieval of identified research, reporting bias). }\end{array}$ & $13-14$ \\
\hline Limitations & 26 & $\begin{array}{l}\text { Provide a general interpretation of the results in the context of other evidence, and } \\
\text { implications for future research. }\end{array}$ & $14-15$ \\
\hline Conclusions & 27 & $\begin{array}{l}\text { Describe sources of funding for the systematic review and other support (e.g., supply of } \\
\text { data); role of funders for the systematic review. }\end{array}$ & $\begin{array}{c}\text { Additional } \\
\text { File }\end{array}$ \\
\hline \hline FUNDING &
\end{tabular}

From: Moher D, Liberati A, Tetzlaff J, Altman DG, The PRISMA Group (2009). Preferred Reporting Items for Systematic Reviews and Meta-Analyses: The PRISMA Statement. PLoS Med 6(7): e1000097. doi:10.1371/journal.pmed1000097 